The oil was hydrogenated at 190 to $200^{\circ} \mathrm{C}$. for $5 \mathrm{hrs}$. It hardened to a melting point of 45 to $46^{\circ} \mathrm{C}$.

DOGEISH OIL-A number of samples of this oil have been examined in this laboratory and have proved somewhat difficult to hydrogenate. In one case, a sample of the oil was agitated with copper hydrate for I hr. and then treated with hydrogen, using a catalyzer prepared by precipitating nickel hydrate on a carrier and reducing at $360^{\circ} \mathrm{C}$. Hydrogenation was conducted for $5^{1 / 2}$ hrs, at 180 to $190^{\circ} \mathrm{C}$. The oil did not harden. The catalyzer was filtered out and 5 per cent of a mixture of finely-divided nickel-copper hydrate was added. A current of hydrogen was passed.

EFFECT OF Haloghns, Halogen Componnds, Stifur, Etc., on HydroGENATION OF COTTONSEED OIL

Catalyzer: Nickel Oxide (5 per cent of the weight of the oil) reduced in oil at $250^{\circ} \mathrm{C}$. for $1 / 2 \mathrm{hr}$.

\begin{tabular}{|c|c|c|c|c|c|}
\hline $\begin{array}{l}\text { Expt. } \\
\text { No. }\end{array}$ & $\begin{array}{c}\text { Substance } \\
\text { Added }\end{array}$ & $\begin{array}{l}\text { Per cent } \\
\text { Added }\end{array}$ & Temp & $\begin{array}{l}\text { Time } \\
\text { Hrs. }\end{array}$ & $\begin{array}{c}\text { Effect on } \\
\text { Oil }\end{array}$ \\
\hline 1 & Bromine & 1.0 & 200 & 2 & No hardening \\
\hline l $(\mathrm{CH})$ & & 1.0 & 200 & 2 & \\
\hline $\begin{array}{l}2 \\
2(\mathrm{CH})\end{array}$ & Iodine & $\begin{array}{l}1.0 \\
1.0\end{array}$ & $\begin{array}{l}200 \\
200\end{array}$ & $\frac{2}{2}$ & \\
\hline $3(-n)$ & & $\begin{array}{l}1.0 \\
0.5\end{array}$ & 200 & $21 / 2$ & \\
\hline $3(\mathrm{CH})$ & & 0.5 & 200 & $21 / a$ & \\
\hline $4(\mathrm{CH})$ & Antimony Bromide & le 1.0 & $\begin{array}{l}200 \\
200\end{array}$ & $\frac{2}{2}$ & \\
\hline $5(-11)$ & Sodium Chloride & 5.0 & 210 & $21 / 2$ & Oil hardened \\
\hline $\begin{array}{l}6 \\
7\end{array}$ & Zinc Chloride & $\begin{array}{l}5.0 \\
1.0\end{array}$ & $\begin{array}{l}210 \\
200\end{array}$ & $\begin{array}{l}21 / 2 \\
2^{1 / 2}\end{array}$ & $\begin{array}{l}\text { Oil polymerized } \\
\text { Slight hardening }\end{array}$ \\
\hline $7(\mathrm{CH})$ & & 1.0 & 200 & $21 / 2$ & Oil Hardened \\
\hline $\begin{array}{l}8 \\
9\end{array}$ & Tin Chloride & $\begin{array}{l}0.5 \\
1.0\end{array}$ & 200 & $\frac{2}{2}^{1 / 2}$ & \\
\hline 10 & Sulfur & 0.5 & 200 & $21 / 2$ & Slight hardening \\
\hline $10(\mathrm{CH})$ & & 0.5 & 200 & $21 / 2$ & Oil hardened \\
\hline $11(\mathrm{CH})$ & & $\begin{array}{l}1.0 \\
1.0\end{array}$ & 200 & $\begin{array}{l}21 / 2 \\
21 / 2\end{array}$ & $\begin{array}{l}\text { No hardening } \\
\text { Oil hardened }\end{array}$ \\
\hline Blank & & & 200 & $21 / 2$ & \\
\hline 12 & Sulfur & 0.1 & 210 & $31 / 2$ & \\
\hline & Red Phosphorus & 1.0 & 200 & 2 & Slight hardening \\
\hline $\begin{array}{l}13(\mathrm{CH}) \\
14\end{array}$ & & $\begin{array}{l}1.0 \\
0.5\end{array}$ & $\begin{array}{l}200 \\
200\end{array}$ & $\begin{array}{l}2 \\
2\end{array}$ & $\begin{array}{l}\text { Oil hardened } \\
\text { Slight hardening }\end{array}$ \\
\hline $14(\mathrm{CH})$ & & 0.5 & 200 & 2 & Oil hardened \\
\hline 15 & Sulfur Chloride & 1.0 & 200 & 2 & No hardening \\
\hline $15(\mathrm{CH})$ & 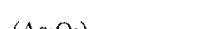 & 1.0 & 200 & 2 & Oil hardened \\
\hline $\begin{array}{l}16 \\
17\end{array}$ & $\begin{array}{l}\left.\text { (Ast2 } \mathrm{O}_{3}\right) \\
\text { Mercury }\end{array}$ & $\begin{array}{l}1,0 \\
1,0\end{array}$ & $\begin{array}{l}200 \\
200\end{array}$ & 2 & $\begin{array}{l}\text { No hardening } \\
\text { Slight hardening }\end{array}$ \\
\hline Blank & & & 200 & $2^{1 / 2}$ & Oil hardened \\
\hline $\begin{array}{l}18 \\
19\end{array}$ & $\begin{array}{l}\text { Lead stearate } \\
\text { Lead Oleate }\end{array}$ & 1.0 & $\begin{array}{l}200 \\
200\end{array}$ & $21 / 2$ & No hardening \\
\hline $19(\mathrm{CH})$ & & i. 0 & 200 & $21 / 2$ & \\
\hline
\end{tabular}

(CH) after an experiment number indicates treatment with copper hydrate before hydrogenation.

through the oil, the temperature of the oil being held at $250^{\circ} \mathrm{C}$. for $1 / 2 \mathrm{hr}$., then lowered to $\mathrm{r} 90$ to $200^{\circ} \mathrm{C}$. and maintained at that point for 3 hrs. The oil hardened to a melting point of $45^{\circ} \mathrm{C}$.

Probably the most difficult to handle of all the lowgrade oils is that derived from city garbage. There are two methods of reclaiming this grease, one by boiling the garbage with water and allowing the oil to rise to the top when it is drawn off, the other by extracting the oil with solvents. This oil is usually denatured with or contains tar, and as it is derived from all manner of materials which would vary from day to day it is quite probable that no fixed method of treatment can be employed. $\tau_{p}$ to the present time no entirely satisfactory method has been found to refine and successfully harden this material in a manner capable of general commercial application.

\section{EXAMINATION OF COPPER HYDRATE}

The copper hydrate which had been used to detoxicate the cod and other oils was examined to determine what bodies were taken up from the oils by the treatment. Fatty material was removed from the copper hydrate by extraction with solvents and the residue was analyzed. Sulfates were found but no evidence of the presence of phosphates or chlorides was obtained. A blank test on the original copper hydrate showed no sulfates or sulfur present, indicating that sulfur compounds are removed from fatty oils containing them, by treatment with copper hydrate in the manner stated.

\section{OTHER CATALYZER POISONS}

As various bodies other than those mentioned above are known to poison hydrogenating catalysts, and as the treatment with copper hydrate has been found to remove certain of these poisons or render them non-toxic to nickel catalyzer, the accompanying table has been compiled from an extensive series of tests with such bodies and in some cases the effect of copper hydrate thereon is indicated.

NEW JERSEY TESTING LABORATORIES, MONTCLAIR

\section{EXPERIMENTAL NOTES ON THE PREPARATION OF FIRE-PROOF WRITING PAPER}

By Rolin G. Myers

Received May 22, 1916

The writer made a careful study of the methods for the preparation of fire-proof writing paper, as well as of the character of the paper obtained by such processes. He extended this work to include the paper produced from crysotile fiber when this was combined, as pulp, with white or lightly tinted precipitated compounds of the metals. These pulps were prepared at about $100^{\circ} \mathrm{C}$.

The method used in the preparation of the paper was identical, in many respects, to that employed by the Japanese in the preparation of their hand-made paper from the vegetable and animal fibers. Each sample prepared was tested for porosity, tensile strength and permanence to temperatures varying from $900-1000^{\circ} \mathrm{C}$. during a period of about io hours: 80 or 90 samples of paper were prepared.

The following inferences appear to be truthful interpretations of the experimental studies:

I-The commercial varieties of crysotile fiber used as raw material in the preparation of the paper were not to be distinguished in respect to mutability at high temperature, porosity, tensile strength and Alexibility.

2-Within certain limits, variations in the quantity of the chemical reagents used for a given weight of fiber produced no observable gain in tensile strength and the reduction of porosity in the paper prepared.

3-Tensile strength and closeness of texture of the paper prepared appears to be obtained best from pulps containing precipitated hydroxides, arsenites, silicates and tungstates. Perhaps the best paper prepared, in respect to the properties referred to, was that obtained from a pulp containing a considerable excess of magnesium arsenite in an alkaline mixture. This paper was far in advance of any of the commercial papers examined.

It might be well to note that most of the above 
precipitates are flocculent in character, and that increase in closeness of texture and tensile strength is not always concurrent.

4-Substances like kaolin or pulverized mica, when incorporated with the pulps, do not seem to add anything to the paper produced.

5-In all the pulps, there exists a certain amount of adhesion between the fiber and the precipitated substance. This attraction is greatest for the precipitated salts of the more basic metals like calcium and magnesium, and least for the more acid metals like silver or lead. This adhesive effect may be due to some chemical action between the fiber and the precipitate.

6-The degree of porosity of all samples increased rapidly when they were heated for any length of time above $100^{\circ} \mathrm{C}$., the cause of the increase of porosity being undoubtedly the contraction in bulk of the precipitated substance in the paper.

7-Tensile strength, and smoothness of surface only, seem to be enhanced by pressing with a warm iron.

8-From the identity of crysotile to "true asbestos" and the general character of the foreign substances used, the indications are pretty clear that no foreign substance either acting by itself or with others can increase the chemical stability of asbestos towards fire.

9-Under the experimental conditions set for the heat or "fire test," $i$. e., a temperature varying from goo$1000^{\circ} \mathrm{C}$. with a time interval of ro hours, it seems probable that no paper composed of incombustible substances containing molecular water is fire-proof or can be made fire-proof. This inference can be extended to "true asbestos" on account of its general similarity in properties and composition to crysotile.

It is true, however, that several samples of paper prepared by the writer, were not seriously impaired when exposed to a dull red heat for an hour or so. These samples still possessed considerable flexibility and could be handled, if a certain degree of care was used. There are some varieties of "true asbestos" which cling to their zeolitic(?) water with a great deal more persistence than crysotile. Paper made from asbestos of this sort would of course be quite well adapted for the preparation of, e. g., fire-proof records. In general then, when lower temperatures and shorter time limits are considered, it is very probable that an entirely satisfactory fire proof paper can be prepared.

ro-In respect to fire-proof inks, solutions of ferric, chromic and cobaltous nitrates and chlorides were used. They stood the "fire test" well. According to Franz Cirkel in the Canadian Government bulletin "Asbestos-Its Exploitation and Uses" no inks up to that time prepared would stand a red heat-excepting perhaps those produced from platinum. For inks other than those prepared from platinum, one condition seems to be necessary, that the acid oxides in the paper should be kept in excess.

TULANE UNIVERSITY OF LOUISIANA, NEW ORLEANS

\section{A HIGHLY UNSATURATED HYDROCARBON IN SHARK LIVER OIL}

By Mrtsumaru Tsujimoto

Received March 21, 1916

Although ustually small in their quantities, hydrocarbons seem to occur in fatty oils more frequently than hitherto considered. Some of them may possibly be utilized for the identification of individual fats and oils.

P. Matthes and $O$. Rohdeck ${ }^{1}$ isolated a hydrocarbon of the composition $\mathrm{C}_{30} \mathrm{H}_{48}$ from cacao butter. It was considered most likely identical with amyrilene. The former chemist, together with H. Sander, ${ }^{2}$ obtained a hydrocarbon from laurel oil and named it laurane. It had the composition $\mathrm{C}_{20} \mathrm{H}_{42}$ and formed a fine needle crystal of m. p. $69^{\circ} \mathrm{C}$. from its alcoholic solution. According to another investigation of Matthes and W. Heintz, ${ }^{3}$ a hydrocarbon of the composition $\mathrm{C}_{20} \mathrm{H}_{42}\left(\mathrm{~m}, \mathrm{p} .69^{\circ} \mathrm{C}\right.$.) occurs in parsley seed oil and was named by them petrosilene. A hydrocarbon, $\mathrm{C}_{31} \mathrm{H}_{64}$ (m. p. $67-68^{\circ}$ C.), is stated to occur in kôsam seed oil (Power and Lees).

In the domain of animal oils, especially in insect oils, hydrocarbons occur in considerable amounts and are characteristic of them. So, from chrysalis oil, Menozzi and Moreschi4 isolated two hydrocarbons: one of them had the composition $\mathrm{C}_{28} \mathrm{H}_{58}$, melted at $62.5^{\circ} \mathrm{C}$. and was optically active, while the other melted at $4 \mathrm{I}^{-4} 2^{\circ} \mathrm{C}$. Further, hydrocarbons were obtained from cantharide and Melolontha oils. ${ }^{5}$

The study of substances, beside sterols, in the unsaponifiable matter of oils and fats, so-called "stearolfree unsaponifiable matter," has lately much attracted the interest of the oil chemist. These substances consist mainly of hydrocarbons, alcohols and ketones. Thanks to the classical researches of Windaus, an effectual means for the separation of sterols from these substances was introduced into fat analysis by the use of digitonin.

The reports of J. Marcusson and G. Meyerheim, ${ }^{6}$ as well as P. Berg and J. Angerhausen, ${ }^{7}$ have satisfactorily confirmed the importance of the investigation of a stearol-free unsaponifiable matter. The latter chemists have devised, on the ground of the examination of this matter, a differentiation method of mowrah and shea butters, the distinction of which is not feasible by ordinary fat analysis.

Of marine animal oils, shark liver oil contains, as is well known, a high percentage of unsaponifiable matter, and appears to furnish a very suitable material for the above-mentioned investigation. In the literature of fats, however, we find but meagre descriptions of the oil; some statements even appear to be conflicting at a glance.

1 Ber., 1908, 41.

2 Arch. d. Pharm., 1908, 165.

3 Ber., 1909, 325.

- Rend. accad. dei Lincei, 1908, 95.

$\checkmark$ Mosquito fat is likely to contain hydrocarbon (W. Normann, Chem. Rev., 1913, 187)

- $Z$. angew. Chem, 1914, 201

7 Z. Nahr. Genussm., 1914, Bd. 27, 723; Bd. 28, 73, 145. 